\title{
Co-Creation in Living Labs to Accelerate Innovation
}

\author{
Jonas Anund Vogel ${ }^{1 *}$, Ellen Van Bueren ${ }^{2}$, Leendert Verhoef ${ }^{3}$, Brian Goldberg ${ }^{4}$, Per Lundqvist ${ }^{5}$ and Emma Sarin ${ }^{6}$ \\ ${ }^{1}$ Director KTH Live-In Lab, Royal Institute of Technology, Sweden
}

${ }^{2}$ Urban Development Management, TU Delft, Netherlands

${ }^{3}$ Program Lead Living Labs, Amsterdam Institute for Advanced Metropolitan Solutions, Netherlands

${ }^{4}$ Assistant Director, MIT Office of Sustainability

${ }^{5}$ Energy Technology, Royal Institute of Technology, Stockholm Sweden

${ }^{6}$ Director HSB Living Lab Gothenburg, Sweden

Submission: February 06, 2020; Published: February 24, 2020

*Corresponding author: Jonas Anund Vogel, Director KTH Live-In Lab, Royal Institute of Technology, Sweden

\begin{abstract}
Innovation in the construction sector occurs as stepwise reconfigurations of subsystems, but sometimes the effect of many systems coincides and there is so called radical change. Stepwise reconfigurations of individual systems such as windows, insulation, and heat recovery systems have made it possible to heat buildings with preheated inlet air instead of water radiators. Thus, making building more sustainable, cheaper and resource-efficient; the potential for radical change has been achieved. The question is then why not every new building uses preheated inlet air? The reason is not the lack of innovation or new technologies. It is rather connected to malfunctioning structures related to incentives, collaboration, testing, and validation, resulting in norms and standards that aim to reproduce existing technologies, preferring incremental innovations over radical ones.

This article argues that testbeds and Living Labs are a way to work on complex, multi-stakeholder and urgent problems in a co-creative way. In these labs there are possibilities to test technologies, in systems, in real buildings and cities. There are possibilities to follow-up, measure and adjust; to live, study, work and develop. The Living Labs have the potential of making new technologies standard to use in the course of years instead of decades and thus minimize unnecessary use of resources linked to the construction and use of buildings. In addition, it will help to make technologies more user-friendly, considering user needs, wishes and experiences, thus contributing to the effectiveness of the technologies developed and tested.
\end{abstract}

Keywords: Living lab; Testbeds; Co-creation; Innovation; Sustainability; Multi-stakeholder; Participatory; Impact

\section{Opinion}

People have lived in spaces protected by roofs, walls and floors for quite some time. Excavations from the Denisova cave indicate that while it has been inhabited for around 200,000 years, nearly 100,000 years of cave life witnessed Denisovans co-living with the Neanderthals [1]. Co-living with your relatives is apparently something that works, it is well tested and a functioning part of society. Time passed, experimented also, albeit slowly and moved from caves to self-made homes in wood, stone, clay, etc., a so-called" radical change" or radical innovation, where man no longer had to rely on formations created by nature. Innovation in the construction sector occurs as stepwise reconfigurations of subsystems, but sometimes the effect of many systems coincides and there is a radical change [2]. For example, the water radiator system was widely introduced in the early 1900s and became the dominant heating system in buildings in wide parts of the (colder parts) of the globe. However, stepwise reconfigurations of individual systems such as windows, insulation, and heat recovery systems have led to an alternative heating system which can lead to a next radical change; we can now build without a water heating system and instead have preheated inlet air, as in many warmer countries. We can dispense with a complete technical system and make resource-efficient, more sustainable and cheaper buildings where every square meter can be furnished, and the temperature can be adjusted in real time. We have achieved the potential for radical change. 


\section{Civil Engineering Research Journal}

So why is not every new building heated with preheated inlet air instead of water radiators? Why do we still produce buildings with methods, materials and products very similar to those used a century ago? As a matter of fact, people pay more for century old apartments than new ones, even though they do not fulfil todays requirements related to ventilation, daylight factor, accessibility, or thermal insulation. And people love these old apartments, even though (or because of?) they do not fulfil all todays requirements. There is more to it than just the location premium. Is it because we found the truth about dwellings already in the Denisova cave and cannot identify anything more we would like to have delivered from our buildings? No, most of us can imagine lots of things that would be appreciated in a home. Simple things as the possibility to change temperature during nights/days, increased ventilation when having friends over, automatic shut-down of systems if they are unused (to save energy), and recycling of all resources that are used (heating, cooling, water, waste etc.). How about tuneable lights, depending on activity and amount of daylight? How about sharing of resources with surrounding buildings? And with other infra-systems such as cars and their batteries as electrical energy storage? All this is possible today, but far from standard and requires acceptance from both industry and users. The reason is not that we lack innovation or new systems or technologies. No, it is because of the malfunctioning structures related to incentives, to collaboration, to testing and validation: these institutions and practices, have been designed within a risk averse context in which innovations tended to be developed and tested in isolation from the environment in which they had to operate. And they have resulted in norms and standards that aim to reproduce existing technologies, preferring incremental innovations over radical ones [3].

In line with the thinking and arguing of the Nobel prize laureate Ester Duflo in her article "The economist as a plumber" [4], we argue that there is a need to engage in the real life settings related to buildings and cities, we need to do some real plumbing work to get innovation and to become sustainability a desired goal for all, instead of a dedicated few. We need to investigate the tapdesign and laying of the pipes related to the built environment.

Our answer is to test things, in testbeds and Living Labs. These Labs are a way to work on complex, multi-stakeholder and urgent problems in a co-creative way [5-7]. We must test technology, in systems, in real buildings and cities. We must follow, measure and adjust; we have to live, study, work and develop in and together with these buildings and cities. Together, we can make new technology standards to use in the course of years instead of decades and thus minimize unnecessary use of resources linked to the construction and use of buildings. In addition, it will help to make the technologies more userfriendly, considering user needs, wishes and experiences, thus contributing to the effectiveness of the technologies developed and tested. This plea for real-life experimentation has been around in urban planning for some years, with participatory approaches [8] having developed into modes of co-production and co-creation, moving up the participation ladder [9], bursting into comprehensive developments of 'city making' and urban infrastructure development in recent years [10]. Also, in the fields of civil engineering and construction, real-life experimentation can offer a much broader innovation environment than the traditional laboratory, providing an environment for learning-bydoing, while restructuring the innovation ecosystem and fostering the 'external validity' of innovations [11]. Let us work together, using the test facilities we have, and develop the new ones we need.

In Amsterdam, Delft, Stockholm, Gothenburg and Boston a variety of experimenting environments (Living Labs) have been set-up by universities, in close collaboration with the city authorities and industry [5, 12-15]. These labs have been running for several years, yielding promising results, which are of value for the further development and implementation of the innovations tested. However, the vast amount of knowledge on Living Labs is still fragmented and often connected to niche entrepreneurs [16]. A growing number of practitioners find the need to fortify their experience-based knowledge and to exchange ideas and learnings with fellow practitioners, and scientists grapple with the task of making robust and trustworthy statements on the value of living Lab approaches. The question of impact, both in professionalism and in scaling remains a challenge [17]. Connecting our lab efforts and approaches will allow us a unique position to exchange experiences and ways of experimenting and faster innovation pathways, to the benefit of students, our local innovation ecosystems and contributing to the development of shared practices and standards. Also, in strengthening development and replication of methods (learning) and results (impact). In our opinion it is urgent that synchronized efforts are undertaken to connect labs, to replicate methods, and to develop training on lab building..

\section{References}

1. Jacobs Z, Li B, Shunkov MV, Kozlikin MB, Bolikhovskaya NS et al. (2019) Timing of archaic hominin occupation of Denisova Cave in southern Siberia. Nature 565(7741): 594-599.

2. Berkers E, Geels F W (2011) System innovation through stepwise reconfiguration: the case of technological transitions in Dutch greenhouse horticulture (1930-1980). Technology Analysis \& Strategic Management 23(3): 227-247.

3. Arthur WB (1989) Competing Technologies, Increasing Returns, and Lock-In by Historical Events. The Economic Journal 99(394): 116-131.

4. Duflo E (2017) The economist as plumber. American Economic Review 107(5): 1-26.

5. www.liveinlab.kth.se.

6. Steen K, Bueren E Van (2017). The Defining Characteristics of Urban Living Labs. 7(7): 21-33.

7. Verhoef L, Bossert M (2019) The University Campus as a Living Lab for Sustainability A Practitioner's Guide and Handbook. Delft University of Technolog. 


\section{Civil Engineering Research Journal}

8. Healey P (1997) Collaborative planning: Shaping places in fragmented societies. Macmillan International Higher Education.

9. Arnstein SR (1969) A Ladder of Citizen Participation. Journal of the American Planning Association 85(1): 24-34.

10. Marvin S, Bulkeley H, Mai L, Mc Cormick K, Palgan YV (2018) Urban living labs: Experimenting with city futures. Routledge.

11. Walrave B, Talmar M, Podoynitsyna KS, Romme AGL, Verbong GP (2018) A multi-level perspective on innovation ecosystems for pathbreaking innovation. Technological Forecasting and Social Change 136: 103-113.

12. https://www.ams-institute.org/how-we-work/living-labs/
13. https://www.hsb.se/hsblivinglab/

14.https://sustainability.mit.edu/living-labs

15. https://www.thegreenvillage.org/

16. Pesch U, Vernay AL, van Bueren E, Pandis Iverot S (2017) Niche entrepreneurs in urban systems integration: On the role of individuals in niche formation. Environment and Planning A 49(8): 1922-1942.

17. Engels F, Wentland A, Pfotenhauer SM (2019) Testing future societies? Developing a framework for test beds and living labs as instruments of innovation governance. Research Policy 48(9): 103826.

Your next submission with Juniper Publishers will reach you the below assets

- Quality Editorial service

- Swift Peer Review

- Reprints availability

- E-prints Service

- Manuscript Podcast for convenient understanding

- Global attainment for your research

- Manuscript accessibility in different formats

( Pdf, E-pub, Full Text, Audio)

- Unceasing customer service

Track the below URL for one-step submission https://juniperpublishers.com/online-submission.php 